\title{
Fan - N - Pick Technique Towards Students' Motivation In Reading Comprehension At FPBS IKIP Mataram
}

\author{
${ }^{1}$ Fathurrahman Imran, ${ }^{2}$ Aprianoto \\ ${ }^{12}$ English Department, Faculty of Culture, Management, and Bussines UNDIKMA \\ fathurrahmanimran@ikipmataram.ac.id
}

\begin{abstract}
This research aims to know the Fan-N-Pick technique towards students' motivation in reading comprehension. This research is quantitative research with experimental design. The respondends are 40 students which is divided into two groups are experimental and control class. The data is analyzed using descriptive and inferential statistics. The result shows that $t_{\text {tes }}(4.810)$ is higher than that of $t_{\text {table }}(1.671)$ in confidence level of 0.05 and the degree of freedom is 70 . It can be concluded that there is significant effect of Fan-N-Pick technique towards students' motivation in reading comprehension.
\end{abstract}

Keywords: Fan-N-Pick, Motivation, Reading Comprehension

\section{INTRODUCTION}

Motivation is kind of internal drive which pushes someone to do thing in order to achieve something (Harmer, 2001: 51). Students who have strong motivation in learning will do something more than the others and it will affect their achievement.

Fan-N-Pick is one of teaching technique which is highly structured with fun team process for responding to questions. Fan-N-Pick technique gives every teammate a role in a questioning and answering process. According Kagan (2009: 6.25) states that Fann-Pick is cooperative learning technique where teammates play a card game to respond to questions and roles rotate with each new question. This technique is highly structured, but fun team process for responding to questions.

Based on the observation at August, 13 2019, some of the problems was found such as review a concepts, discuss an issue, demonstrate understanding of contents, and share information about a topics. This case found at the first semester of Faculty of Language at Edcation IKIP Mataram.

Based on the problems above, the researcher formulated the problem of the study is "Does Fan-N-Pick technique have any significant effect towards students' motivation in reading comprehnsion at the first semester of FPBS IKIP Mataram in year $2019 ?$.
This study aims to find out whether Fan-N-Pick technique has significant effect towards students' motivation in reading comprehension at the first semester of FPBS IKIP Mataram.

\section{RESEARCH METHOD}

This research is quantitative research with experimental design. The respondends are 40 students which is divided into two groups are experimental and control class. The instrument used questionnaire. The data is analyzed using descriptive and inferential statistics.

\section{FINDING AND DISCUSSION}

The research question on the previous chapter has finally been answered by the statistical analysis in this research. It can be seen that the $t_{\text {test }}$ as the result of the inferential statistical analysis is higher than the $t_{\text {table }}$ (4.810> 1.671). This result showed that there was significant difference between the mean score of students in control group and that of experimental group. It means that there is significant effect of the treatment given in the experimental group for the students motivation. The result of the analysis showed that Fan-N-Pick Technique has significant effect towards students' motivation in reading comprehension.

In using Fan-N-Pick technique the researcher divided the students into some 
groups and every teammate play a card game to respond to questions and roles rotate with each new question. This technique makes the students fun and this technique is highly structured with team process for responding to questions. Each team receives their own set of question or problem cards then try to play with the rule of Fan-N-Pick technique for teambuilding. Fan-N-Pick is great for mastering the content and reviewing the material which was given by the teacher in previous meeting. So, the students more understand with their lesson. In other hand, Fan-n-Pick gives every teammate a role in the questioning and answering process. This keeps everyone actively involved and every teammate gets their turn to answer a question.

In Summary, Fan-N-Pick technique is effective not just because of its capability in boosting the students' interest in learning English, but also because of the students learning, growing, and succeeding in learning process.

\section{CONCLUSION AND SUGGESTION}

Based on the discussion, this study can be concluded those are:

1. Based on the application of $t_{\text {-test }}$ formula, it was found out that the $t$-test, which is (4.810) higher than that $t_{\text {table }}$ (1.671).

2. Using Fan-N-Pick Technique in reading comprehension is effective, meaning that there is significant effect of this technique towards students' motivation.

Based on the conclusion above, hopes that English teachers should use Fan-N-Pick technique in the class because it attractive and fun which is able to make students interest in learning. As the result, the students will actively involve in the process, enjoy the study and learning process to get the best result. Also, the students learn and interact with each other to acquire and practice the elements of a subject matter and to meet common learning goals. In this case the students are able to sharing their knowledge, ability and solving the problem together. The researcher hopes that the result of the study is useful as reference for those who want to conduct further research on Fun-N-Pick technique or motivation in learning reading comprehension.

\section{REFERENCES}

Arikunto, S. (2010). Prosedur Penelitian Suatu Tindakan Praktik. Jakarta: PT. Rineka Cipta , 2007.ManajemenPenelitian. Jakarta: PT. RinekaCipta.

Cox, W. M. and Klinger, E. (2004). Handbook of Motivational Counseling. England: Jhon Wiley and Sons.

Ford, M. E. (1992). Motivating Human: Goal, Emotions and Agency Beliefs. New Delhi: Sage Publication.

Harmer, J. (2001). The Practice of English Language Teaching. Essex: Longman Group UK Limited.

Kagan, S. and Kagan M. (2009). Kagan Cooperative Learning. www. Kagan online.com: Kagan Publishing.

Kagan, S. (2009). Fan-N Pick. www. Kagan online.com: Kagan Publishing.

Miller, S. (2005). Experimental Design and Statistics. Second Edition. United Kingdom: Taylor and Francis eLibrary.

Pierce, W. D. and Cheney C. D. (2004). Behavior Analysis and Learning. United State of America: Lawrence Erlbaum Associates.

Schunk, D. H. (2012). Learning Theory and Educational Perspective. Boston: Pearson Education.

Sing, Y. K. (2006). Fundamental of Research Methodology and Statistics. New Delhi: New Age International.

Sugiyono, (2014), Metode Penelitian Kuantitatif, Kualitatif dan $R \& D$, Bandung: Alfabeta 